\title{
Biting Pattern and Seasonality of Filariasis Vector of Mansonia spp. in Endemic Area of Banyuasin Regency, South Sumatera, Indonesia
}

\author{
Rini Pratiwi ${ }^{1,2}$, Adri Huda ${ }^{2,3}$, Ahmad Ghiffari $^{2,4}$ D, Chairil Anwar ${ }^{1 *}$ \\ ${ }^{1}$ Department of Parasitology, Faculty of Medical Science, Universitas Sriwijaya, Palembang, Indonesia; ${ }^{2}$ Department of \\ Environmental Science, Graduate School, Universitas Sriwijaya, Palembang, Indonesia; ${ }^{3}$ Department of Chemistry, Faculty \\ of Mathematics and Natural Science, Universitas Sumatera Utara, Medan, Indonesia; ${ }^{4}$ Department of Parasitology, Faculty of \\ Medical Science, Universitas Muhammadiyah Palembang, Palembang, Indonesia
}

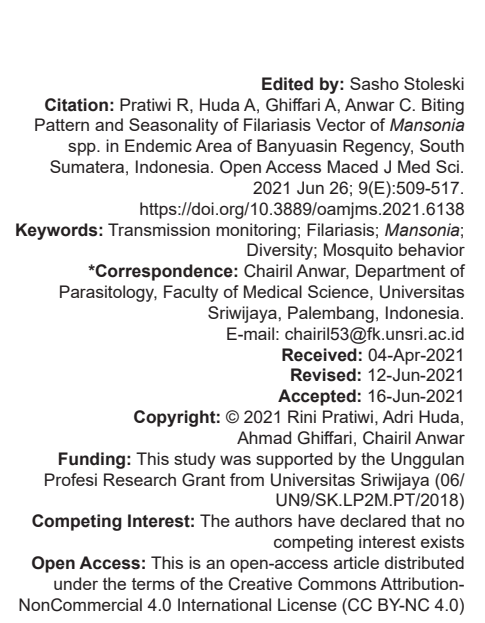

\section{Introduction}

Lymphatic filariasis is a debilitating disease and the prevalent in tropical and subtropical areas such as Asia, Africa, and Australia [1]. The World Health Organization determines that South Asia region faces $55.7 \%$ of at the world risk population where $94.6 \%$ and $85.2 \%$ of the reported having lymphoedema and hydrocoele cases globally [2]. In general, filariasis is an infection of microfilariae by Wuchereria bancrofti, Brugia malayi, and Brugia timori which transmitted by mosquitoes [3], [4], [5]. Approximately 23 species of mosquito from five genera which are Mansonia, Anopheles, Culex, Aedes, and Armigeres are reported as the vectors of Iymphatic filariasis [6], [7], [8], [9]. To be more specific, the genera of Mansonia spp. have been implicated in the transmission of filariasis in many regions of Asia [10]. In South Sumatera, Indonesia, our previous study has successfully identified the biodiversity of mosquitoes in Sedang villages as the endemic area of filariasis and found that Mansonia spp. was one of the most prevalent mosquitoes in Sedang Village and Muara Sugih [11]. In case of filariasis cases, the survey conducted during the 1983-2002 found that the average microfilarial rate was $2.02 \%$ and the number of filariasis in 2018 was still 89 cases [12]. The number of lymphatic filariasis cases is still high and the understanding of transmission becomes the primary importance for the further control strategies.

Herein, the present study aims to investigate the prolonged biting behavior of Mansonia spp. by collecting and investigate its $24 \mathrm{~h}$ activity patterns of Mansonia spp. in Sedang and Muara Sugih villages as the endemic area of filariasis. The understanding of biting pattern provided us the valuable information to determine the further prevention activity. Thus, exploring the behavior of Mansonia spp. can lead an approach to control filariasis vectors in endemic area of filariasis. 


\section{Materials and Methods}

The research area was Sedang village and Muara Sugih where the detailed location can be seen in our previous work paper [11]. The collecting data of biting activity were conducted using human landing collecting method developed by Gimnig et al. (2013) and Barnard et al. (2014) with several modification of collector and period of time [12], [13], [14]. The collection data were performed by six groups of collector divided into two groups for investigating the indoor and outdoor conditions. The collection period was 14 months started from April 2017 to May 2018. Each group in indoor and outdoor was managed to sit in the chair in the specific area for $40 \mathrm{~min}$ to let the mosquitoes doing biting activity. The mosquitoes were trapped using aspirator and transferred to the paper cup with a cotton soaked in sugar water. The number of mosquitoes was recorded in the end of the test and divided into several categories such as diversity, abundance, and man biting rate (MBR).

The diversity was determined after investigating the mosquitoes species. The abundance was recorded by calculating the number of mosquito as the function of mosquitoes species in percentage (\%) (Equation 1) [11]. The total of collected mosquitoes was divided into the number of collector in the period of collection time (per month) to obtain the MBR (Equation 2). To analyze the specific patterns of each species of Mansonia spp., the seasonal biting activity of each Mansonia spp. was performed to see when the high peak of biting activity occurred. All the analysis of biting behavior was assessed with t-test analysis to statistically study the significance of prolong biting behavior occurred in both studied areas.

$$
\text { Abundance }(\%)=\frac{£ \text { per species }}{£ \text { collectedmosquitos }} \times 100 \%
$$

$$
\text { Manbiting rate }=\frac{£ \text { collected mosquito per species }}{£ \text { collector } \times £ \text { period of collection }}
$$

\section{Results and Discussion}

\section{The collection of mosquitoes caught in Sedang and Muara Sugih villages}

The total number of mosquitoes collected in Banyuasin Regency in the collection period was 14,757 mosquitoes where 4455 mosquitoes and
10,302 mosquitoes collected in Sedang village and Muara Sugih village, respectively. The species identification identified 15 genera of all the collected mosquitoes 13 genera found in Sedang village and 10 genera found in Muara Sugih village. In Sedang village, the specific genera were Mansonia, Culex, Aedes, Anopheles, Coquilettidia, Topomyia, Armigeres, Triptoides, Miomyia, Malaya, Uranataenia, Hodgesia, and Urotonia. In Muara Sugih village, the genera were Culex, Aedes, Mansonia, Anopheles, Coquilettidia, Lutzia, Topomyia, Uranotaenia, Malaya, and Udaya consist as the domestic genera. Furthermore, the species identification 36 species and 40 species identified in Sedang village and Muara Sugih village, respectively. However, the study was only specified Mansonia spp. which found as filariasis vector on our previous study [11], [15]. Therefore, only Mansonia spp. was used to further identifications.

The number of Mansonia spp. caught during this period was 4956 individuals where 4448 mosquitoes caught in Sedang village and 508 mosquitoes caught in Muara Sugih village. The diversity of Mansonia spp. in Sedang village was found as six species: Mansonia uniformis, Mansonia annulifera, Mansonia indiana, Mansonia bonneae, Mansonia annulata, and Mansonia dives. In Muara Sugih village, there was no $M$. annulata detected indicating only five species collected in the study. The environmental characteristics of both studied areas differentiated the diversity of Mansonia spp. Sedang village was consisted of swamp area and Pistia stratiotes as the water plant which potentially become the suitable breeding area of Mansonia spp. However, the environmental characteristics of Muara Sugih village were dominated by open field such as plantation and paddy field where paddy plant (Oryza sativa) as the aquatic plant dominant. The open area and paddy plant require the strong flier of mosquitoes to reach the breeding site or resting site. Therefore, Muara Sugih village was not suitable for Mansonia spp., especially $M$. annulata which was categorized as the weak flier compared to the other species of Mansonia spp. [16]. The detail percentage of collected Mansonia spp. in the study area is shown in Figure 1.

M. uniformis was found as the dominance mosquitoes showed by the high percentage caught in both studied areas. It indicated that the type areas of swamp and paddy field were the suitable place for M. uniformis to breed and do resting. Besides, the

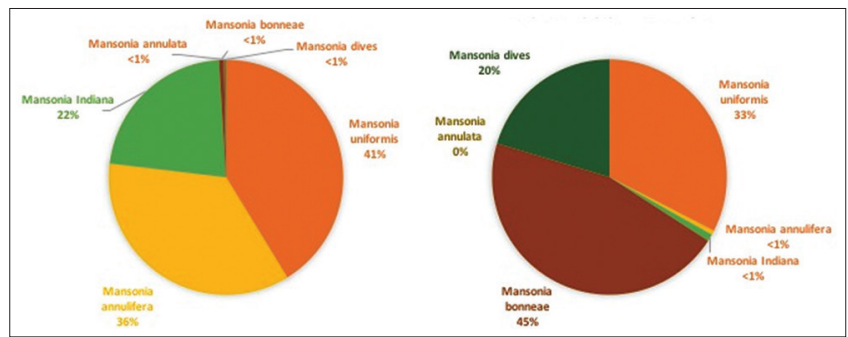

Figure 1: The percentages of Mansonia spp. in Sedang village and Muara Sugih village 
swamp area in Sedang village was only suitable for $M$. annulifera and $M$. indiana. On the other hand, $M$. bonneae and $M$. dives became the most collected species in Muara Sugih village, indicating that the paddy field and paddy plant were suitable for M. bonneae and $M$. dives to breed and rest during their activities.

The findings showed the fingerprint of the studied area as the diversity of mosquitoes where the characteristics of percentage of collected mosquito should be different with the other area. For example, a similar research about the diversity of mosquitoes conducted in Brazil which has the specific weather and tropical characteristic (similar with the studied area) reported that there was a small amount of Mansonia spp. collected during the research period $(<1 \%)$ [17]. Near the studied area, Malaysia, Chen et al. (2017) also reported the similar study where only 3.5\% Mansonia spp. consisted from all the collected mosquitoes [18]. The study confirmed that a change in the environment significantly impacted, directly or indirectly, the behavior and bionomics of mosquitoes. The local climate parameters and the physicochemical properties had a great role in determining the distribution and diversity of these vectors, because the transmission of vectortransmitted diseases as limited by the vectors' tolerance to local climate [19], [20].

\section{Seasonal MBR of Mansonia spp.}

In Figure 2, the seasonal patterns for M. uniformis, M. annulifera, and $M$. indiana in Sedang village were similar with bimodal peaks; a big peak in April-July 2017 and a small peak after July 2017. The highest peak of biting rate was found in April 2017 and continually decreases until June 2017. Furthermore, the MBR was fluctuated from July 2017 to May 2018, indicating the unimodal peak in April 2017-March 2018.

The rainfall level was used to see the effect of season to the biting activity. The result showed that the high season of rainfall (wet season) began in October 2017-May 2018 did not provide any significant to the high number of MBR, indicating that the rainfall level did not provide a significant effect to the mosquito activity. However, the main reason why the rainfall did not

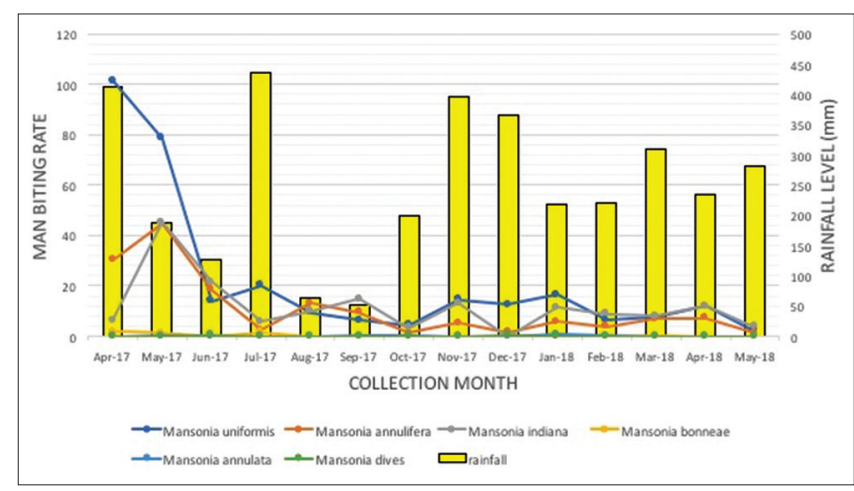

Figure 2: Man biting rate of Mansonia spp. and the rainfall patterns at Sedang village provide any significant effect was because two possible reason. First, the rainfall potentially washed all the larvae in the surface of water resulting the low number of mosquitoes. Second, the nutrients and pollutant containing in the water as the mosquito breeding site reduced with the high rainfall level made the water cleaner which was not a good site for breeding site [21].

The seasonal MBR and rainfall pattern of M. uniformis, M. annulifera, M. indiana, M. bonneae, and $M$. dives in Muara Sugih village are shown in Figure 3. The seasonal patterns for $M$. uniformis $M$. bonneae, and $M$. dives were fit with bimodal peaks; with the big peak in April 2017-September 2017 and the small peak after September 2017. M. indiana and $M$. annulifera had only an unimodal small peak June 2017-May 2018. The result in Muara Sugih village was quite similar with the result in Sedang village where the rainfall pattern did not provide any significance occurrence to the number of MBR. The highest peak of MBR occurred in May 2017, April 2017, and May 2018 where the pattern of rainfall was relatively decreased in those periods. Therefore, the rainfall pattern had no significant effect to the seasonal biting activity of Mansonia spp. in both studied areas.

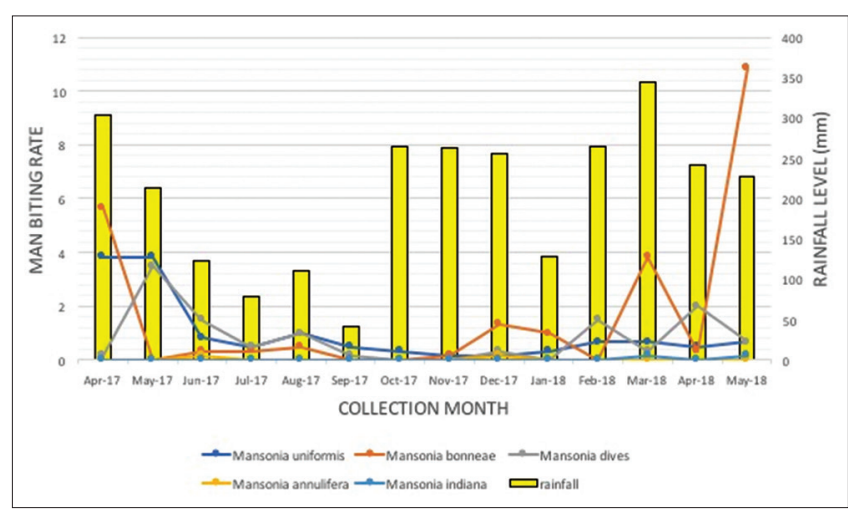

Figure 3: Seasonal variation in man biting rate of Mansonia spp. and rainfall patterns at Muara Sugih village, Tanjung Lago district

The investigation of biting behavior of Mansonia spp. found that the mosquito activity decreased gradually from August 2017 to October 2017 and increased after November 2017. The peak was increased again in March 2018 and having the highest peak at May 2018 of the collection period. The main species performing the highest MBR in Sedang village were $M$. uniformis, $M$. annulifera, and $M$. indiana while $M$. bonneae, $M$. uniformis, and $M$. dives were found as the dominant in Muara Sugih village.

The seasonal patterns for $M$. annulata and M. bonneae were similar with bimodal peaks; a small peak in May-August 2017 and a big peak after August 2017. Both $M$. uniformis and $M$. indiana had a unimodal peak in April 2017-October 2017. The biting of $M$. bonneae occurred in high numbers throughout the study period, ranging from 4.3 bites per person-hour in April to 24.3 bites per person-hour in October 2017. M. indiana had lower rates (0.2-5.7 bites per person-hour). 
M. annulata bit people at the highest rate of 31.7 bites per person-hour in October 2017 but occurring no bite cases in April 2017-August 2017. In conclusion of MBR in Muara Sugih village, Mansonia activity increased gradually from April 2017 to October 2017 with the first peak (28.5 bites person-hour) in July 2017 followed by a greater peak in October 2017. M. uniformis and $M$. indiana were the main species comprising the highest biting density in April-August 2017, while $M$. annulata, $M$. bonneae, and $M$. dives formed the bigger subsequent peak in August-December 2017.

\section{The investigation of biting behavior}

\section{The hourly biting behavior of mosquitoes}

The host seeking of biting behavior of anthropophagic Mansonia spp. as the feeding time was studied in two villages of Banyuasin Regency, South Sumatera, using $24 \mathrm{~h}$ collection method. The understanding of biting behavior played the important role since it provides the detailed information about the high activity periods which further indicated the most possibilities of transmission time. However, the further investigation about the hourly collection was conducted only to the highest biting pattern of the collection mosquitoes which were $M$. uniformis, M. annulifera, and $M$. indiana for Sedang village and $M$. uniformis, M. bonneae, and M. dives for Muara Sugih village. The investigation was conducted in both indoor and outdoor conditions to see the most dominant condition of each species to feed themselves as the biting behaviors. The biting pattern of Mansonia was then reported as a function of time started from 18:00 to 17:00 in next day (24 $\mathrm{h}$ investigation period).

Figure 4 shows the highest biting activities of $M$. uniformis in Sedang village which began at approximately after sunset (18.00-20.00) and slightly decreases at 21.00-22.00 for outdoor and indoor, respectively. After the high peak of biting activities, the activities were relatively fluctuating during the midnight and after midnight to early morning at 06.00. The biting activity was fluctuating but relatively going up after 08.00 in the next day. Furthermore, the biting activities of $M$. uniformis were quite similar in the morning, noon, afternoon, and evening, indicating that the biting behavior of $M$. uniformis was whole day in both indoor and outdoor.

Figure 5 shows the highest biting activities of $M$. annulifera in Sedang village which began at approximately 18.00 and fluctuated in high peak until 05.00. The highest peak was found in the evening started at 19.00-22.00. The result confirmed that M. annulifera was the nocturnal species [22]. However, the small activities were detected after the midnight where the biting activity was fluctuated in the morning and afternoon. To be specific in indoor activities, $M$. annulifera relatively showed similar biting activities in $24 \mathrm{~h}$ with the highest peak at the sunset (19.00). In conclusion, the night and noon biting behavior were quite similar for $M$. annulifera in indoor but having a slightly different in outdoor. However, this finding proved that $M$. annulifera had the whole day biting behavior in indoor and outdoor conditions.

Figure 6 presented that the highest biting activities of $M$. indiana in Sedang village were similar with the other Mansonia spp. in which the high peak season began after the sunset (18.00). The indoor activities started at 18.00, decreased from 19.00, and have a fluctuating pattern until 17.00 in the next day. In outdoor activity, the highest peak was similar with indoor activity in which the high biting activity started at 18.00 and having the highest biting activity at 19.00

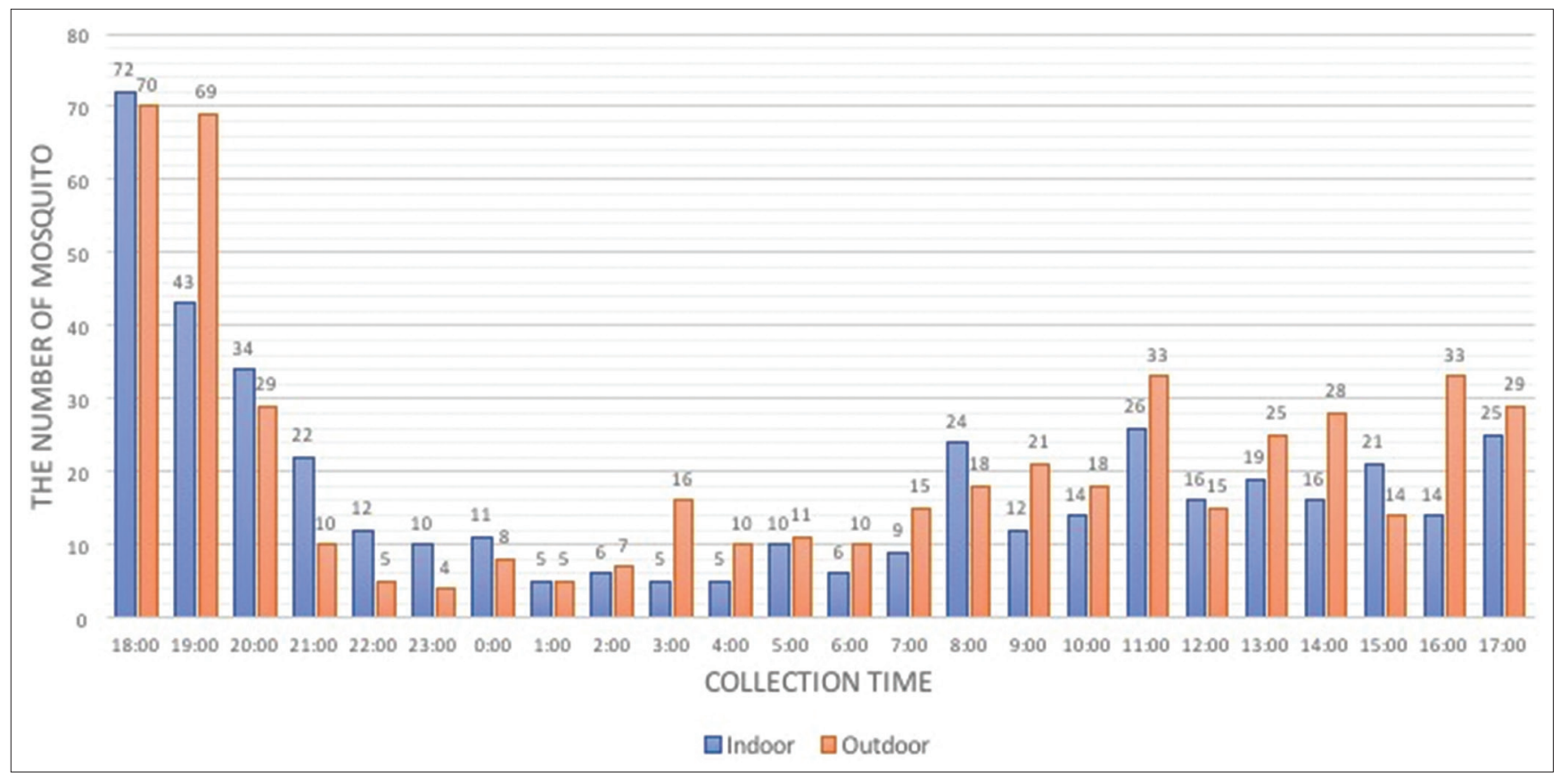

Figure 4: Indoor and outdoor biting behavior of Mansonia uniformis in Sedang village investigated in $24 \mathrm{~h}$ biting periods 


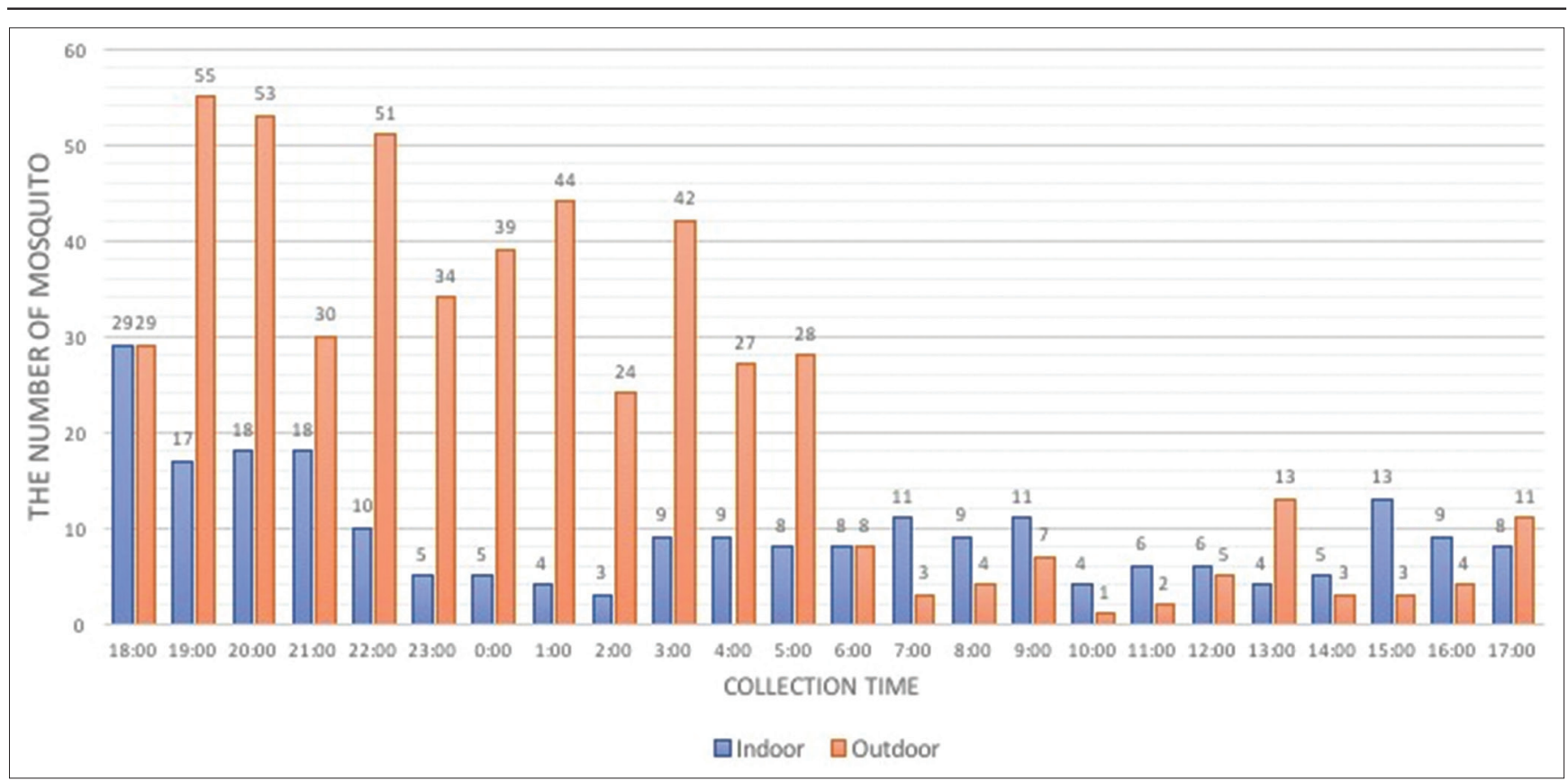

Figure 5: Indoor and outdoor biting behavior of Mansonia annulifera in Sedang village investigated in 24 h biting periods

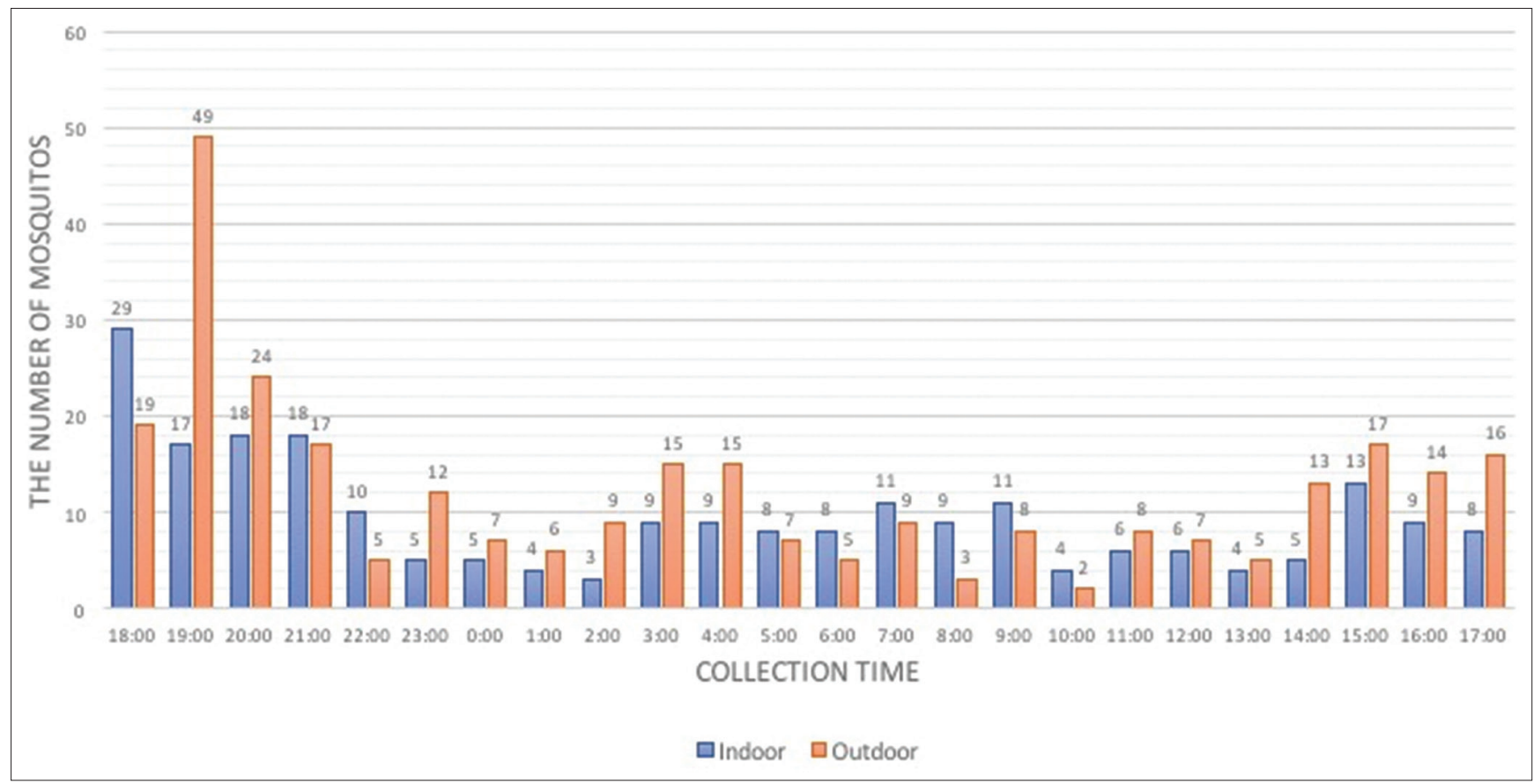

Figure 6: Indoor and outdoor biting behavior of Mansonia indiana in Sedang village investigated in $24 \mathrm{~h}$ biting periods

and slightly decrease after the highest peak season and form the fluctuating activity whole the collection time. Comparing both conditions, $M$. indiana has higher activities in outdoor than indoor condition, but relatively similar activities during all days. It concluded that $M$. indiana biting behavior was whole day in both indoor and outdoor.

The study was continued by seeing the biting activities of $M$. uniformis in Muara Sugih village (Figure 7). The highest biting activities of $M$. uniformis were similar with the result at Sedang village (18.00 in outdoor and 19.00 in indoor). However, by comparing the number of $M$. uniformis collected in Sedang village, the collected $M$. uniformis was extremely small in number. The environmental characteristics of Muara Sugih village which consist of paddy plant and open field resulting in the strong flier mosquitoes found in high number such as Culex spp. [23]. The small number of collected mosquitoes was because $M$. uniformis only bite the human target at the night to the morning (18.00-08.00). However, only one M. uniformis found at 16.00 in outdoor condition.

Figure 8 shows the biting activities of M. bonneae in Muara Sugih village. The biting periods were began at 18.00 and continuously decreased in number after midnight with the highest peak of biting 


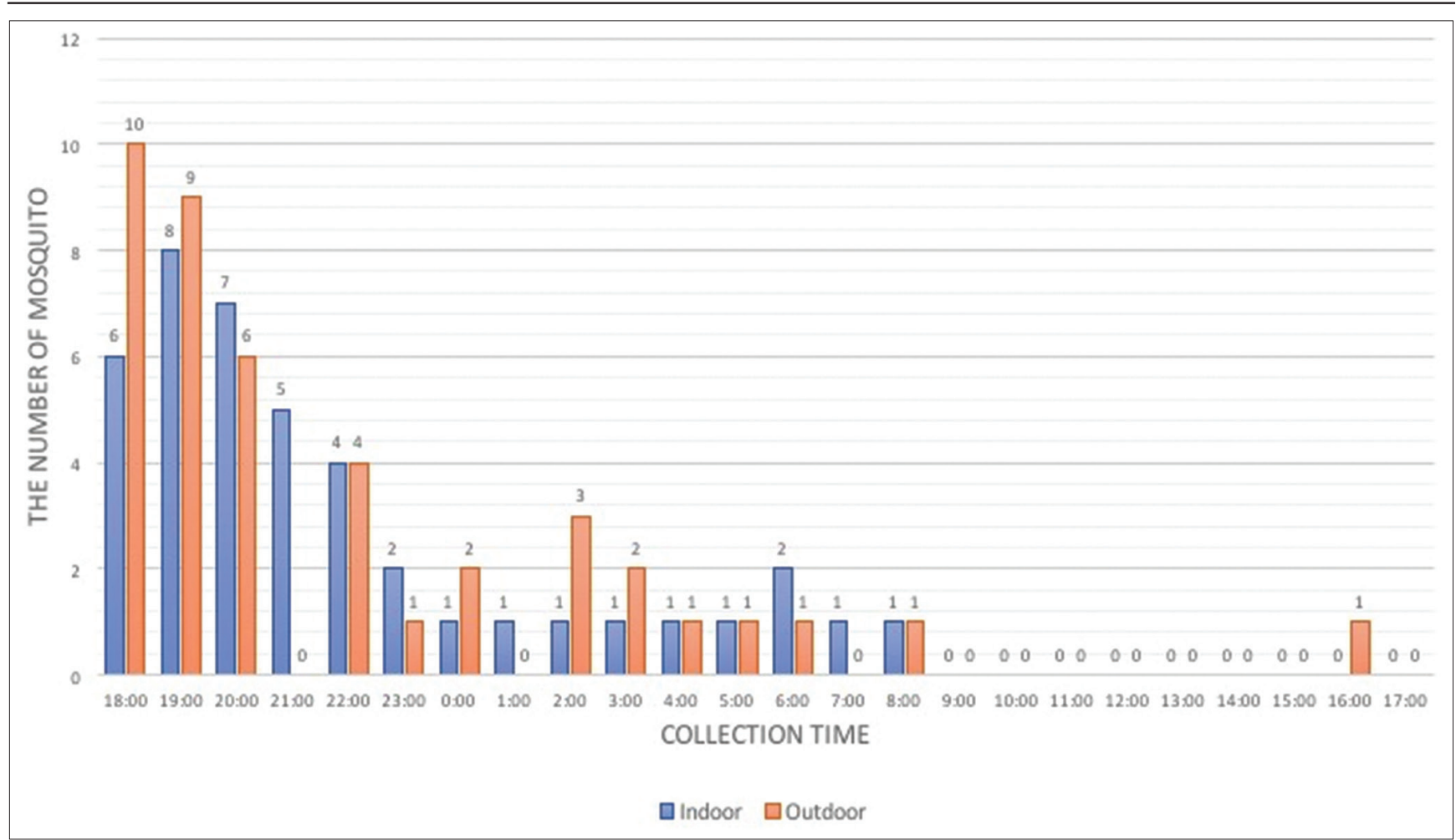

Figure 7: Indoor and outdoor biting behavior of Mansonia uniformis in Muara Sugih village

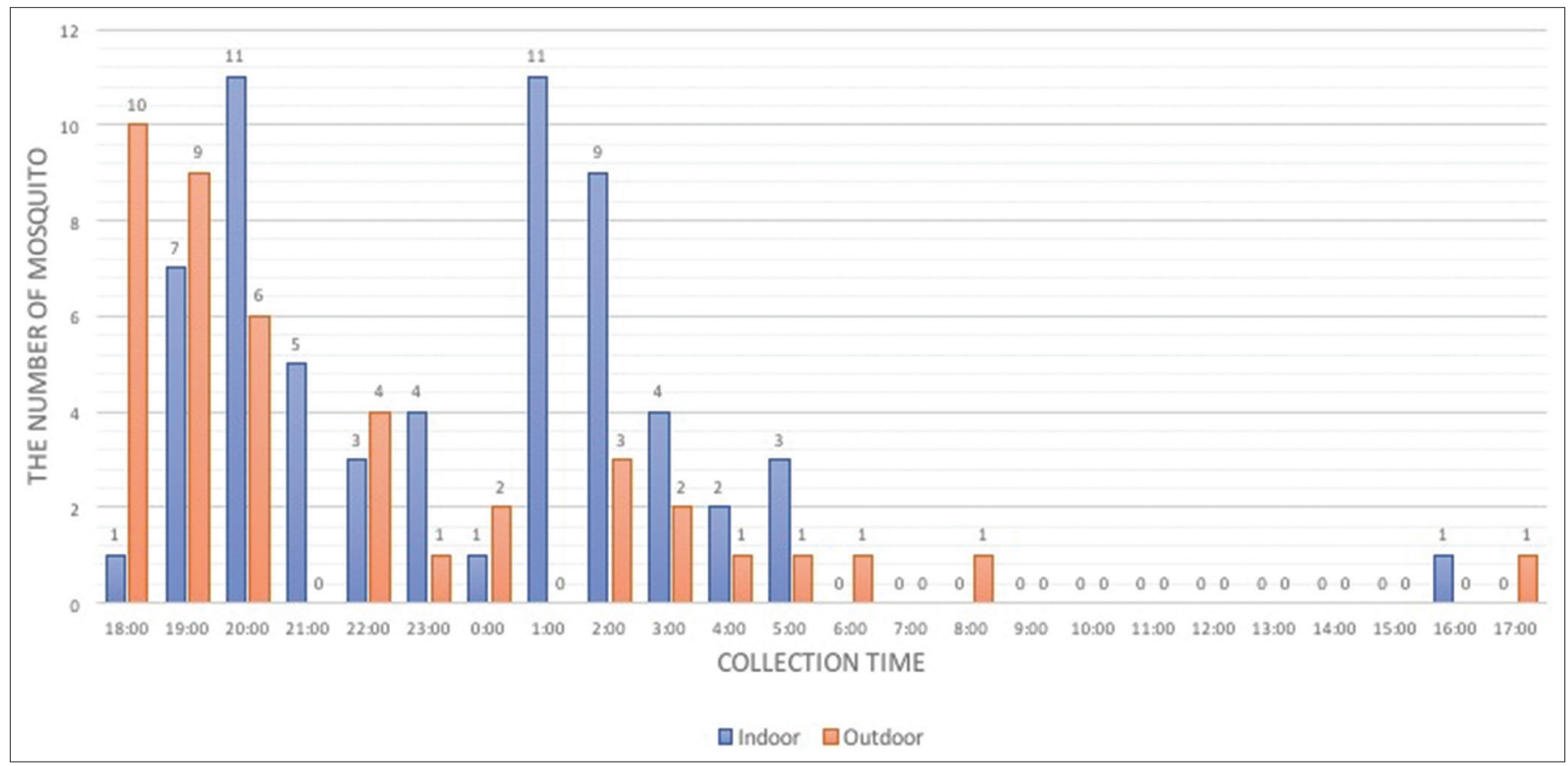

Figure 8: Indoor and outdoor biting behavior of Mansonia bonneae in Muara Sugih village

activities 20.00 for the outdoor and 19.00 and 01.00 for the indoor. Similarly, $M$. dives in Muara Sugih village showed a similar pattern where the mosquito started doing the feeding period at 18.00 in outdoor and 20.00 for indoor (Figure 9). The detail biting pattern of M. dives in Muara Sugih can be seen in Figure 9. The period of biting was only active during the night with small activity at outdoor in the morning (08.00 and 10.00).

The biting behavior of Mansonia spp. in Sedang village and Muara Sugih village had different pattern. The presence of three major species in Sedang village had biting pattern in whole day, meanwhile in Muara Sugih village, the most dominant mosquito only active in the night. Our finding was different with the result of Apiwathnasorn et al. (2006) which collected Mansonia spp. mosquitoes in Thailand [24]. The collected Mansonia spp. has the biting activity in the noon which the high biting activity started at 09.00 in the morning with the highest peak occurred at 10.00 . However, the activity decreased in the afternoon (12.00-17.00). Near to our studied area, Rohani et al. (2013) investigated the biting activity of mosquito in Sarawak, Malaysia, 


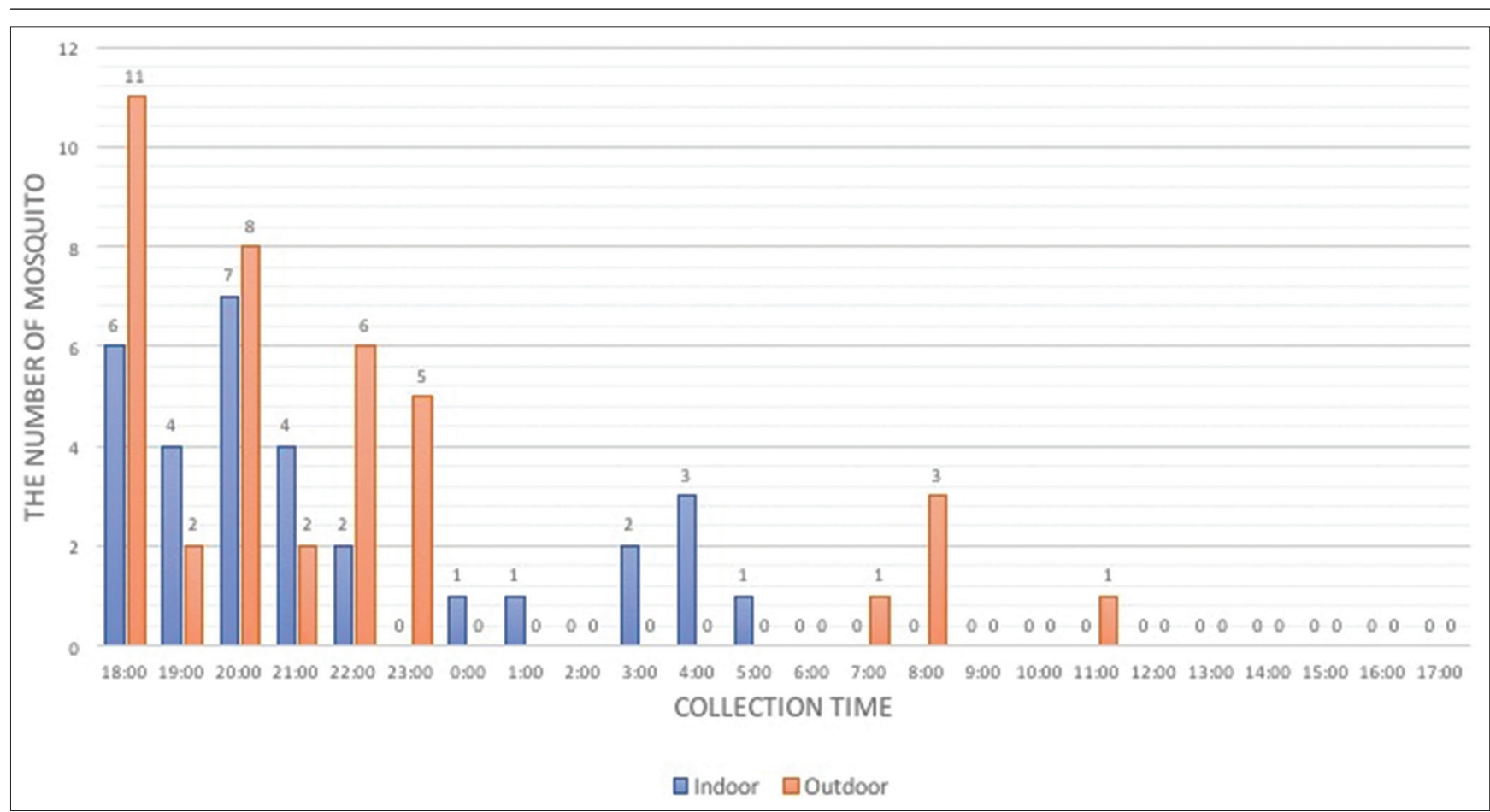

Figure 9: Indoor and outdoor biting behavior of Mansonia dives in Muara Sugih village

and found the similar result in which $M$. bonneae started the biting activity at 19.00 and with the highest peaked at 20.00. The pattern was similar with our finding in which the biting activity was dramatically decrease after the highest peak [25] However, Rohani et al. found that there was no biting activity of Mansonia spp. in day time, indicating our result about the whole day activity of Mansonia spp. becoming interesting findings. The result proved that the different study area would generate different biting behavior, transmission possibilities, and characteristic of mosquitoes.

\section{Prolonged biting activity}

The statistical analysis was further used to determine the distribution time of biting activities of Mansonia. in both study areas. In Sedang village area, the average mosquitoes caught during the day (06.00-17.00) and the night (18.00-05.00) were quite similar. The $p$-value calculation showed 0.230 which is higher than the significant value $(\alpha)$ of 0.05 , indicating that there was no difference in the average number of mosquitoes biting activities in Sedang village area during the day and the night (Table 1). There was a behavior changing of Mansonia spp. which commonly active at night (nocturnal) prolonged to be active at noon (diurnal).

Table 1: The biting activity base on time in Sedang village

\begin{tabular}{llllll}
\hline Biting activity & $\mathrm{n}$ & Mean & SD & t-test & -value \\
\hline Day & 171 & 11.97 & 18.25 & -1.203 & 0.230 \\
Night & 165 & 14.62 & 22.05 & & \\
\hline
\end{tabular}

In Muara Sugih village area, the statistical analysis using t-test exhibited the p-value of 0.03 which less than the significant value $(\alpha)$ of 0.05 . The statistical analysis indicated significant different in the biting behavior of Mansonia spp. in the night and noon day (Table 2) indicating Mansonia spp. as the nocturnal species. Furthermore, the highest biting activity of Mansonia in Muara Sugih village was similar to Sedang village which was at 18.00-20.00. However, the biting activity pattern was only during the night and only small number of mosquitoes caught in the morning and noon.

Table 2: The biting activity base on time in Muara Sugih village

\begin{tabular}{llllll}
\hline Biting activity & $\mathrm{n}$ & Mean & SD & t-test & p-value \\
\hline Day & 39 & 2.56 & 2.68 & 2.182 & 0.03 \\
Night & 297 & 1.43 & 3.09 & & \\
\hline
\end{tabular}

The further statistic investigation was conducted by comparing the biting activity of Mansonia spp. in both studied area and analyzed the prolong biting activities. The result showed that Mansonia spp. in Sedang village had prolonged biting activity which shown by the higher number of biting activity during the day $(50.9 \%)$ than night $(49.1 \%)$. In Muara Sugih village, Mansonia only had $11.6 \%$ during the day and $88.4 \%$ during the night. However, the small amount of prolong biting activities was still made in Muara Sugih village and becomes the interesting issue for the next research to investigate if Mansonia spp. in both studied areas have changed their behavior. The statistical analysis concluded that prolonged biting activity of Mansonia was only found in Sedang village which provided the high-risk ratio (RR) (8 times greater risk of transmission of disease with $95 \%$ of confidence interval 5.31-11.73 shown in Table 3).

The biting activity changed the profiles across the boundaries of species and countries [13]. In this study, 
Table 3: Comparison of Mansonia biting activity in Sedang village and Muara Sugih village

\begin{tabular}{llllll}
\hline Study area & \multicolumn{2}{l}{ Biting activity changes $(\%)$} & Total $(\mathrm{n}=672)$ & $\mathrm{RR}(95 \% \mathrm{Cl})$ & $\mathrm{p}$-value \\
\cline { 2 - 4 } & Yes & No & & & \\
\hline Sedang & $171(50.9)$ & $165(49.1)$ & 336 & $7.89(5.31-11.73)$ & 0.000 \\
Muara Sugih & $39(11.6)$ & $297(88.4)$ & 336 & & \\
\hline
\end{tabular}

M. uniformis could be captured during the daytime, mostly in shaded locality and the biting pattern of each mosquito species varied widely. The differences of the result could be due to the level of adaptation displayed by each species in different areas and environment. However, most of mosquito species typically started to hunt for blood meal shortly before sunset (18.00) and usually reach their peaks during the succeeding $1-3 \mathrm{~h}$ at night (20.00).

The daily flight activities of Diptera mosquitoes, from Culicidae family, were dominated for mating, feeding, and oviposition. Of all these activities, the feeding on blood was the most important, because of its disease transmission properties and the fact that it would cause discomfort for the host [26]. The majority of mosquitoes including Mansonia spp. were nocturnal, in which several finding found Mansonia spp. having high biting activities in the afternoon (15.00-16.00). However, these conditions were happened in the specific condition of high humidity and ambient temperature $\left(25-28^{\circ} \mathrm{C}\right)$ [21] The change of biting activity or prolong biting activity of Mansonia spp. occurred in noonday and after midnight potentially increased the case of lymphatic filariasis. It was supported by the biting pattern approaches the nocturnal subperiodic pattern of $B$. malayi [11], [15].

\section{Conclusion}

There were six species of Mansonia spp. caught in Sedang village and five species caught in Muara Sugih village which potentially transmitted the filariasis disease in Banyuasin, South Sumatera, Indonesia. The biting pattern of those mosquitoes was relatively similar both outdoors and indoors in which most of the mosquitoes have the high biting behavior at 18.00 . However, there was a prolong biting activity detected in Sedang village during the noonday where Mansonia spp. was known as a nocturnal mosquito. The result becomes the valuable information to arrange the further controlling action of filariasis transmission in Sedang and Muara Sugih villages as the endemic area of filariasis in South Sumatera, Indonesia.

\section{Acknowledgments}

We would like to thank the Health Department of Banyuasin regency, also the Eijkman Institute,
Jakarta, for cooperating with this study. The study was founded by Unggulan Profesi Research Grant Universitas Sriwijaya, 06/UN9/SK.LP2M.PT/2018.

\section{References}

1. Dickson BF, Graves PM, McBride WJ. Lymphatic filariasis in mainland Southeast Asia. A systematic review and metaanalysis of prevalence and disease burden. Trop Med Infect Dis. 2017;2(3):32. https://doi.org/10.3390/tropicalmed2030032

2. World Health Organization. World health organization globa programme to eliminate lymphatic filariasis: Progress report 2015. Wkly Epidemiol Record. 2016;91:441-60.

3. Maldjian C, Khanna V, Tandon B, Then M, Yassin M, Adam R, et al. Lmphatic filariasis disseminating to the upper extremity. Case Rep Radiol. 2014;2014:985680. https://doi. org/10.1155/2014/985680

\section{PMid:24707427}

4. Dickson BF, Graves PM, Aye NN, New TW, Wai T, Win SS, et al The prevalence of lymphatic filariasis infection and disease flowing six rounds of mass drug administration in Mandalay Region, Myanmar. PLoS Nigl Trop Dis. 2018;12(11):e0006944. https://doi.org/10.1371/journal.pntd.0006944

5. Molyneux D. Lymphatic filariasis (elephantiasis) elimination: A public health success and development opportunity. Filaria J. 2003;2(1):13

PMid:13129436

6. Haryuningtyas D, Subekti DT. Deteksi mikrofilaria/larva cacing Brugia malayi pada nyamuk dengan polimerace chain reaction. JITV. 2008;13(3):240-8.

7. Chandra G. Nature limits filarial transmission. Parasit Vectors. 2008;1(1):13.

PMid:18500974

8. Kariuki MM, Hearne LB, Beerntsen BT. Differential transcript expression between the microfilariae of the filarial nematodes, Brugia malayi and B. pahangi. BMC Genomics. 2010;11(1):25. https://doi.org/10.1186/1471-2164-11-225

9. Tan LH, Fong MY, Mahmud R, Muslim A, Lau YL, Kamarulzaman A. Zoonotic Brugia pahangi filariasis in a suburbia of Kuala Lumpur City, Malaysia. Parasitol Int. 2011;60(1):111-3. https://doi.org/10.1016/j.parint.2010.09.010

PMid:20951228

10. Onapa AW, Pedersen EM, Reimert CM, Simonsen PE. A role for mansonia uniformis mosquitoes in the transmission of lymphatic filariasis in Uganda? Acta Trop. 2007;101(2):159-68. https://doi. org/10.1016/j.actatropica.2007.01.003

PMid:17316535

11. Pratiwi R, Anwar C, Salni S, Hermansyah H, Putra R, Huda A Species diversity and community composition of mosquitoes in a filariasis endemic area in Banyuasin District, South Sumatera, Indonesia. Biodiversitas. 2019;20:453-62. https://doi. org/10.13057/biodiv/d200222

12. Dinas Kesehatan Kabupaten Banyuasin. Profil Dinas Kesehatan Kabupaten Banyuasin. Jakarta: Pangkalan Balai; 2016. https:// doi.org/10.48093/jiask.v3i1.31

13. Gimnig JE, Walker ED, Otieno P, Kosgei J, Olang G, Ombok M et al. Incidence of malaria among mosquito collectors conducting human landing catches in Western Kenya. Am J Trop Med Hyg. 2013;88(2):301-8. https://doi.org/10.4269/ajtmh.2012.12-0209 PMid:23249685

14. Barnard DR, Dickerson CZ, Murugan K, Xue RD, Kline DL, 
Bernier UR. Measurement of landing mosquito density on humans. Acta Trop. 2014;136:58-67. https://doi.org/10.1016/j. actatropica.2014.04.019

PMid:24769003

15. Ghiffari A, Pratiwi R, Anwar C, Dalillah. Monitoring Lymphatic Filariasis Interventions through Adult Mosquito PCR sampling in South Sumatera Province, Indonesia. Vol. 8. International Conference and the $10^{\text {th }}$ of the Entomological Society of Indonesia (ICCESI 2019); 2019. p. 224-28. https://doi. org/10.2991/absr.k.200513.039

16. Gass RF, Deesin T, Sucharit S, Surathin K, Vutikes S. Dispersal and flight range studies on Mansonia annulata, Mansonia indiana, and Mansonia uniformis (Diptera: Culicidae) in Southern Thailand. J Med Entomol. 1983;20(3):288-93. https:// doi.org/10.1093/jmedent/20.3.288

PMid:6135807

17. De Carvalho GC, Ceretti-Junior W, Barrio-Nuevo KM, Christe RO, De Paula MB, Vendrami DP, et al. Composition and diversity of mosquitoes (Diptera: Culicidae) in urban parks in the South region of the city of São Paulo, Brazil. Biota Neotropica. 2017;17(2):1-7. https://doi.org/10.1590/1676-0611-bn-2016-0274

18. Chen C, Wan N, Nurin Z, Lee HL, Faezah K, Izzul A, et al. Biting behaviour of medically important mosquitoes (Diptera: Culicidae) in Peninsular Malaysia. Trop Biomed. 2017;34(1):199-211. PMid:33592999

19. Bashar K, Rahman MS, Nodi IJ, Howlader AJ. Species composition and habitat characterization of mosquito (Diptera: Culicidae) larvae in semi-urban areas of Dhaka, Bangladesh. Pathog Glob Health. 2016;110(2):48-61. https://doi.org/10.1080 /20477724.2016.1179862

PMid:27241953
20. Mazigo HD, Mboera LE, Rumisha SF, Kweka EJ. Malaria mosquito control in rice paddy farms using biolarvicide mixed with fertilizer in Tanzania: Semi-field experiments. Malaria J. 2019;18(1):226. https://doi.org/10.1186/s12936-019-2861-4 PMid:31286986

21. Okorie PN, Popoola KO, Awobifa OM, Ibrahim KT, Ademowo GO Species composition and temporal distribution of mosquito populations in Ibadan, Southwest Nigeria. J Entomol Zool Stud. 2014;2(4):164-9.

PMid:25520960

22. Foster WA, Walker ED. Mosquitoes (Culicidae). In: Medical and Veterinary Entomology. $3^{\text {rd }}$ ed., Ch. 15. Cambridge: Academic Press; 2019. p. 261-325. https://doi.org/10.1016/ b978-0-12-814043-7.00015-7

23. Ciota AT, Drummond CL, Ruby MA, Drobnack J, Ebel GD, Kramer LD. Dispersal of Culex Mosquitoes (Diptera: Culicidae) from a wastewater treatment facilitiy. J Med Entomol. 2012;49(1):35-42. https://doi.org/10.1603/me11077 PMid:22308769

24. Apiwathnasorn C, Samung $Y$, Prummongkol S, Asavanich A, Komalamisra N, Mccall P. Bionomics studies of Mansonia mosquitoes inhabiting the peat swamp forest. Southeast Asian J Trop Med Public Health. 2006;37(2):272-8. PMid:17124985

25. Rohani A, Zamree I, Najdah W, Mohamad W, Hadi AA, Asmad M, et al. Nocturnal man biting habits of mosquito species in Serian, Sarawak, Malaysia. Adv Entomol. 2013;1(2):42-9. https://doi. org/10.4236/ae.2013.12009

26. Departemen Kesehatan RI. Pedoman Ekologi dan Aspek Perilaku Vektor. Jakarta: Departemen Kesehatan; 2004. 